\title{
Discussion on University Teaching Reform under the Education Massification
}

\author{
Mingjun $\mathrm{Li}^{1 *}$ \\ ${ }^{1}$ School of Education Science, Shaanxi Xueqian Normal University, Xi'an, 710100, CHINA
}

Received 8 June 2017 • Revised 14 October 2017 • Accepted 12 November 2017

\begin{abstract}
The overall characteristics of China's higher education development in the new century is that it has entered the stage of massification development, and the reform and development of higher education presents new features. This paper intends to summarize the massification of higher education and discusses development stage and development characteristics of China's higher education massification, and combines with the development of higher education in recent years to analyze the progress of China has made in massification of higher education, and puts forward that China's higher education massification development is changing from pursued and passive mode to the active mode. Systematic research on practical teaching of undergraduate engineering education helps to provide theoretical and practical basis for policy makers of educational authorities, and change the view of practice teaching. In this paper, through literature research, survey research and case analysis, the problems existing in the teaching practice are summarized and the reasons behind the problem are analyzed. The concept of practice teaching is organized to build the standard for cultivating talents of undergraduate engineering education, on this basis, the curriculum content is updated, curriculum system is reconstructed and teaching methods are reformed. The perfection of university practice teaching mechanism promotes the development of university teaching reform and development.
\end{abstract}

Keywords: education massification, university teaching reform, higher education development, education reform, education talent training plan

\section{INTRODUCTION}

With the expansion of university enrollment, the class capacity is increased significantly, students' desire for knowledge is plummeted. The traditional teaching class is boring, more and more students are dissatisfied with teaching, which has become a problem faced by university teachers. According to a survey, the attendance rate of basic courses for university students is below $75 \%$, the attendance rate of professional courses is below $80 \%$, and the attendance rate of some public courses is less than $50 \%$. Some university students are sleepy or play smart phones even though they show up in class. This situation violates the original intention of higher education, and is not conducive to the development of university students. In this class, how to improve class attendance and classroom teaching attraction has become an urgent task (Delmanet al., 2015; Singh-Pillay and Sotsaka, 2017). The starting point of undergraduate engineering education practice teaching reform is based on the development of current and future economic, technological, cultural and the essential characteristics of engineering and education. Under the environment of internationalization, informatization and marketization, talents of engineering science and technology cultivated in universities are difficult to meet the needs of society and industry reform, and the needs of national economic development mode transformation and an innovative country establishment. To this end, we need to re-examine the undergraduate engineering education personnel training objectives, formulate undergraduate engineering education personnel training standards (Shilova and Sibgatullina, 2017). Around the talent training standard, the curriculum system is reconstructed and the teaching method is improved, and the practice link is added actively to train the new technical person, so as to form an effective teaching mode. Starting from the concept system of innovative practice teaching in universities, this paper focuses on the cultivation of 


\section{Contribution of this paper to the literature}

- By analyzing the successful cases of mixed learning in foreign countries, this paper comes up with some enlightenment, and draws lessons from successful mixed learning in foreign countries and applies it to our own research to explore the localization research.

- Through effective teaching design to combine practice teaching and classroom learning, so as to improve students' autonomous learning ability and learning output, and the effective guidance method of mixed learning is obtained.

- Students' interest in classroom learning and class participation rate are improved. The traditional tedious class of low attendance is changed.

students' active practice consciousness, team spirit and lifelong learning ability. In teaching practice, the teaching content should be actively updated and multidisciplinary cooperation between students will be advocated. Through the reform of teaching methods of university education to fuse the core value of undergraduate engineering education concept into the new mode construction of undergraduate engineering education (Deng and Zhang, 2017; Elmunzer et al., 2015).

\section{LITERATURE REVIEW}

\section{Domestic Situation Analysis}

Some suggestions are put forward to promote the practice teaching reform and improve the engineering practice ability of engineering undergraduate students. Academician Yang Shuzi pointed out that China's undergraduate engineering education, mainly focus on high-level professionals of technical and engineering aspects, and even applied advanced professionals (Or-Kan, 2017). Academician Zhou Ji emphasized that "the combination of education, productive labor and social practice", which is the clear requirement put forward by education policy for undergraduate engineering education reform. Engineering education must return to engineering and face engineering practice, which is the direction of undergraduate engineering education reform in China (Gradlet al., 2015; Hismanoglu, 2010). Academician Li Peigen proposed that in the future engineering education, we need to understand the role and significance of practice from a deeper level. Higher schools and teachers should set up "practice normal consciousness", "practice space consciousness", "virtual practice consciousness" and "practice non practice consciousness" (Lawson et al., 2017). In the process of teaching, teachers should inspire and train students' ability of active practice, and guide students to take active practice, which is the key to the cultivation of innovative ability. Academician Gu Binglin believes that in order to develop the analysis and comprehensive ability of undergraduate engineering students and cultivate good quality, comprehensiveness of experiment and engineering training need to be strengthened, and engineering practice activities include: the experiment and engineering training, participance in engineering research projects and internship in factories and enterprises three parts (Hu, 2012; Liu, 2010; Kwon and Block, 2017)). He also trusts that innovative practice is the necessary link to cultivate students' innovative ability, innovative practice education is a direction of engineering education reform. Academician Shi Mingxian put forward that higher engineering education must be returned to engineering and practice. Overall, engineering education should return to engineering and practice, practice teaching can start from two aspects. On the one hand, open the course of engineering practice in universities to let the students participate in the flexible practice project to cultivate students' practical ability; on the other hand, the higher school can cooperate with enterprises to build engineering research center, training base or project cooperation, to cultivate students' practical ability (Manninget al., 2015; Collins and Staples, 2017).

\section{Foreign Situation Analysis}

Engineering universities in the United States actively carry out the reform of curriculum system and teaching methods, and look for their own talent training program and teaching plan. The main course is to adjust and merge the original curriculum, and to realize the integration and intersection of the curriculum. The project of design course mainly comes from the actual engineering problems of the enterprise, and is generally complete by the students in the form of team grouping. The large experiment course is a comprehensive experiment which is set up in addition to the confirmatory experiments that are coordinated with the theoretical courses (Odehet al., 2015). MIT makes full use of teachers' scientific research projects, which are decomposed into all kinds of undergraduate research teaching activities and training projects of engineering practice, there are three current implementing programs: undergraduate practice oriented program, undergraduate research oriented planning and technology business plan. The specific embodiment of universities in the United States are not the same, but the goal and direction of reform have a certain tendency, also are through reforming the existing teaching methods, curriculum 


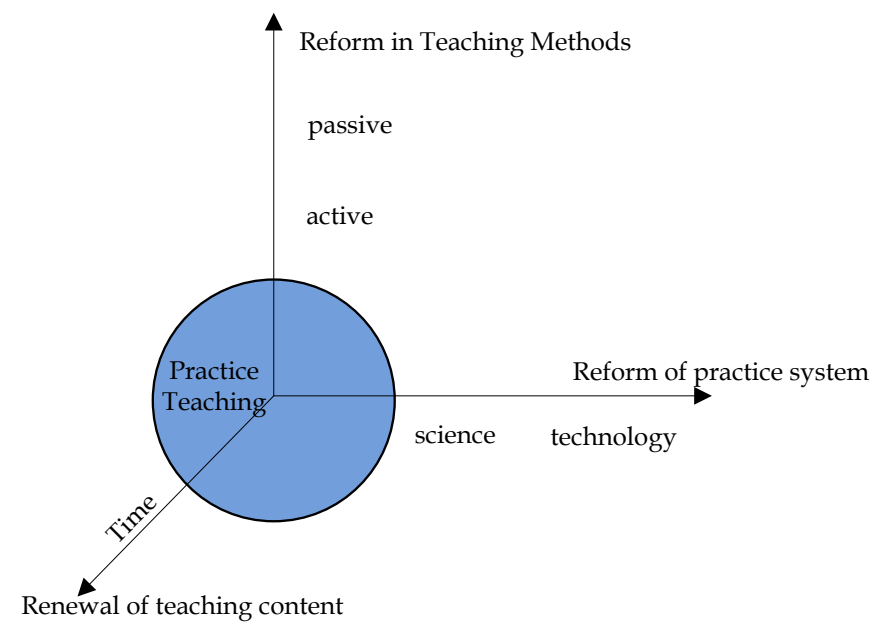

Figure 1. Creative diagram of teaching reform mode

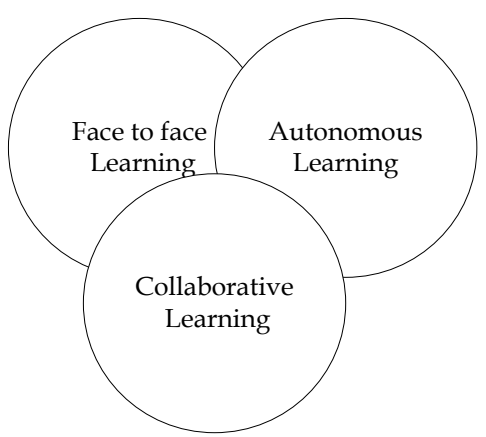

Figure 2. Three element model diagram of mixed learning

system and content, so as to fit the interdisciplinary, comprehensive curriculum and students' engineering practice, teamwork, innovation spirit and creative ability better (Saunders et al., 2015). Associate professor Kong Hanbing in Zhejiang University looked up Massachusetts Institute of Technology, University of California at Berkeley, Imperial College London, Technical University Munich and Kyoto University through the network, and summarized the characteristics of engineering education reform of these engineering universities: problem oriented, students are guided to participate in the research project of teachers, learning interdisciplinary in practice; practice oriented, teaching of engineering design, comprehensive experiment, enterprise practice are strengthened (Starkset al., 2015; Stoehr et al., 2017).

\section{METHODS}

According to the education administrators, students and teachers, to carry out the investigation and analysis of the current situation and problems of the teaching of undergraduate engineering education practice in China, and innovate university teaching reform mode under the background of education massification from the education practice teaching idea, talent training standards, curriculum system and teaching content update, reform of teaching methods and other aspects, as shown in Figure 1 (Yi et al., 2017).

This study not only focuses on normative analysis, but also emphasizes empirical analysis. The main research methods include literature research, survey research, comparative research and case study, etc. (Tala and Vesterinen, 2015). Based on the problem exists in teaching mode of universities in China at the present stage, a mixed practice teaching method is put forward: demand analysis - media selection - teaching design - learning content development and cooperation, understand the degree of attention to the engineering design courses. The object of curriculum design is explored, and the three element model diagram of mixed learning is drawn as Figure 2 (Goren and Yemini, 2017).

The system structure of practice curriculum innovated with the idea of mixed learning is shown as Figure 3. The performance evaluation of the practice assessment can be subdivided into: quality of summarized report; completeness of the schedule and the degree of participation within the deadline; function and performance of the design; complexity, innovation and challenging of design (Wang et al., 2015; Mathews et al., 2017). 


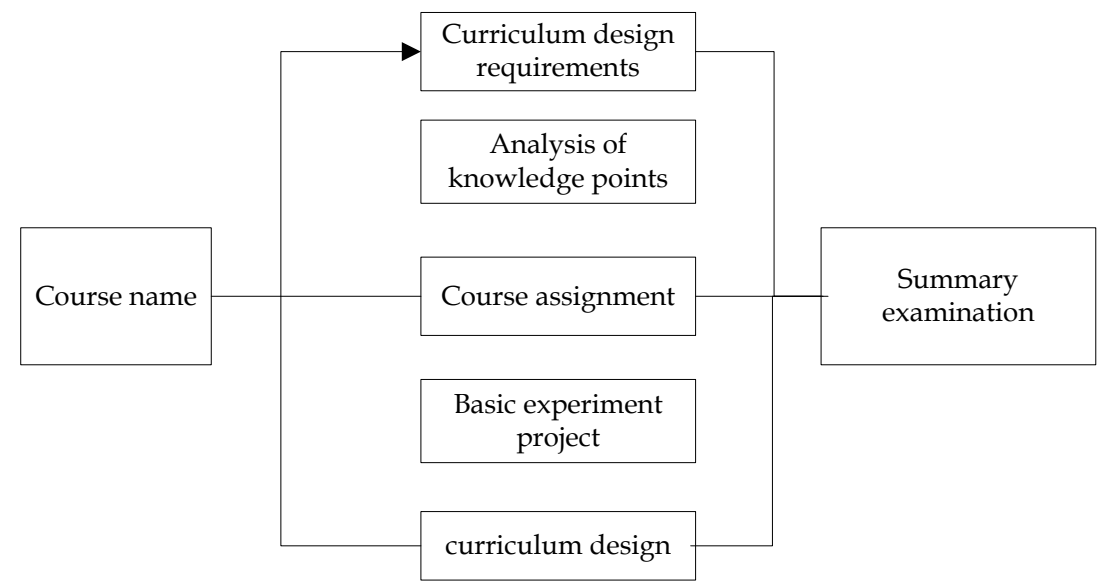

Figure 3. Teaching system design based on mixed learning

Table 1. Evaluation system of practice teaching

\begin{tabular}{lllll}
\hline Practice teaching content Time arrangement & Hours & Credit & Remarks \\
Basic practice & $\begin{array}{l}\text { In grade one, it can be dispersed or } \\
\text { concentrated }\end{array}$ & 6 weeks & 12 & $\begin{array}{l}\text { The internship site is an } \\
\text { internship factory }\end{array}$ \\
\hline Cognitive Practice & Before and after the second summer vacation & 4 weeks & 8 & Basic laboratory \\
\hline Curriculum Design & $\begin{array}{l}\text { In conjunction with the third semester } \\
\text { theoretical course }\end{array}$ & 4 weeks & 8 & $\begin{array}{l}\text { Laboratory and design } \\
\text { classroom }\end{array}$ \\
\hline Production Practice & Before and after the third summer vacation & 5 weeks & 10 & $\begin{array}{l}\text { Outside school practice base, } \\
\text { laboratory and so on }\end{array}$ \\
\hline Graduation Project & Eighth semesters & 8 weeks & 16 & Decentralized \\
\hline
\end{tabular}

\section{RESULTS}

After the establishment of the scientific practice teaching system, the specific content of practice teaching need to be arranged and designed, to achieve the goal of practical teaching according to the characteristics and current situation of China's higher education, practice teaching content should take $25 \%-30 \%$ of teaching content. Practice teaching hours should be accounted for $20 \%-25 \%$ of teaching hours (Zhao, Wang, Chang, 2013). The other part of practice teaching is not in teaching arrangement (Instefjord and Munthe, 2017; Blonder and Sakhnini, 2017).

The content of practice teaching is divided into two parts: in class plan and extracurricular plan. The in-class includes military training, reading report and experiments, practices and graduation thesis (design), extracurricular plan includes a variety of community activities, public service, social investigation, school education, graduate education, extracurricular technological innovation activities. According to the management methods of credit system in universities, the credit of practice teaching should be $20 \%$ of the total credits, and a perfect practice teaching evaluation system should be formulated. The Evaluation system of practice teaching is shown as Table 1 (LaChausse, 2017; Nwagu et al., 2017).

Because the current practice teaching utilizes management machine form of multiple departments, and various departments are took in charge by different leaders, and are facing the specific teaching units. Each department is responsible for the macro management, and implementation of practice teaching content is assigned to each teaching unit specifically. This kind of management style is not conducive to the implementation of practice teaching plan, especially cannot meet the implementation of the practical teaching plan after reform (Zhonget et al., 2015). Therefore, it is necessary to improve the management mechanism of practice teaching in enterprises and institutions outside the school, and establish the consultation and communication mechanism with the school to manage students. Therefore, a common management mechanism must be established, as shown in Figure 4 . 


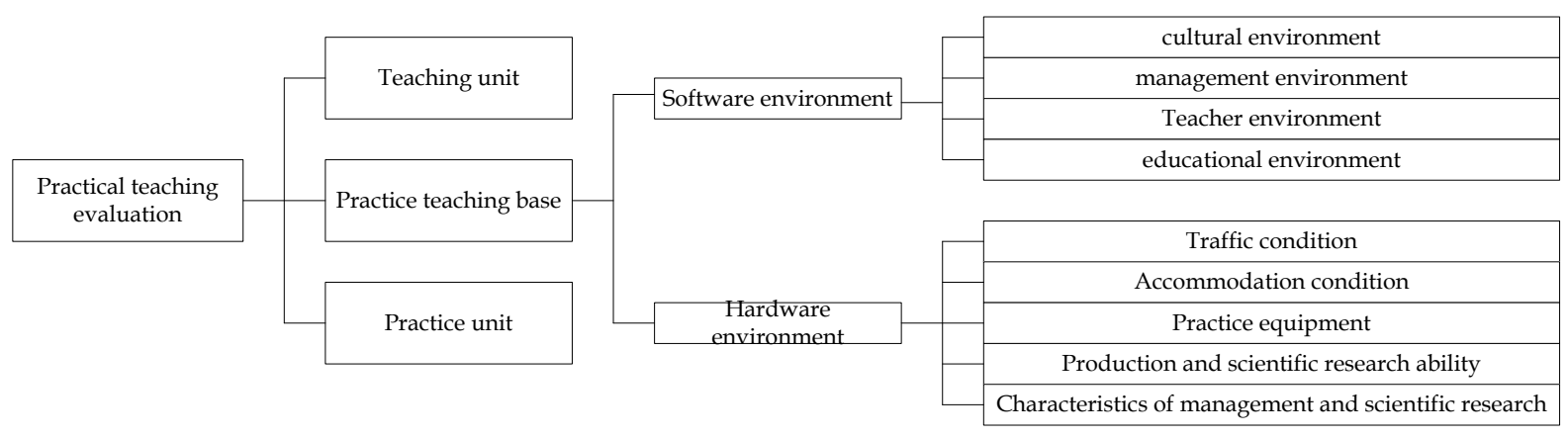

Figure 4. Innovation model of practice teaching evaluation mechanism

Among them, the practice score is $\varphi$, the basic knowledge utilization and mastering ability of students are $\alpha$, the number of students practice is $n$, and the score of students practice skills is $\varphi$, then the following formula is obtained:

$$
\varphi_{2}=\frac{\varphi_{1}+\alpha \varphi_{i}+(1-\alpha) \varphi_{(i-1)}+\cdots+\varphi_{n}}{0+\cdots+\alpha+\cdots+(1-\alpha)+\cdots+n}
$$

The evaluation index system of practical teaching is divided into three parts: the overall evaluation index system of practice teaching, the phased evaluation index system of practice teaching, and the evaluation index system of practice teaching unit. The formula is utilized to calculate the score of practice teaching evaluation, according to the results of student evaluation to conduct targeted counseling for students, and promote the cultivation of students' practical ability (Akre and Suris, 2017; John and Zapata Roblyer, 2017).

\section{DISCUSSION}

For a long time, in the phase of elite education, universities in China set the goal as cultivating professional talents, that is, so-called elite talents, the teaching reform has always followed the "elite" training mode to improve the internal logic-based on the elite talents. The professional training plan is developed to clarify that "elite" is the theoretical and academic talents. The consciousness of cultivation of the elite is established and the elite cultivation environment is created (Harris, 2017; Han, Lee, 2017). The curriculum with certain difficulty and depth are set to optimize the curriculum system from the students' knowledge, ability and quality, in order to make the structure, goals, curriculum modules more adapt to the elite personnel training requirements. In terms of the training target, the elite education focuses, on the thick foundation, wide caliber, high technology in the cultivation of knowledge training, and on the innovation ability and practice ability, management ability, international exchange ability in the ability cultivation etc. (Neto and Wilks, 2017). However, the students cultivated through the "elite" training mode cannot adapt to the demand of employment market for technical and skilled human resources, therefore, more reflection and discussion about the personnel training mode are triggered. Especially when China's higher education gross enrollment rate exceeded 15\% in 2002 and entered the massification stage of development, people in advocating the quality view of higher education from "elite" to "mass" at the same time, put forward strong questioning and criticizing of a single "elite" training mode. Then, some people even suggest that the university should focus on cultivating the gray collar talent and applied talents. Any practical teaching project, from content design to organization and implementation, has the problem of scientific evaluation. Although the consideration of various factors, from every point of view, as far as possible to design the practice teaching content in accordance with the requirements of science, and meet requirements of students' development, in accordance with the requirements of the development of the subject, so as to achieve the intended purpose. But in the process of practical teaching, if the practice teaching content is really in line with itself leaves problems related to evaluation. When it comes to implementation and effect, the significance of evaluation is self-evident. Practice teaching project evaluation can make the content of practice teaching more in line with scientific requirements. The rationality of the content of a project can only be tested in the actual operation process. After a period of implementation, with the development of higher education, each project of practice teaching must be evaluated to make it more aligned with the needs of development. The evaluation of practical teaching project is of great importance to improve the implementation and management of practical teaching projects. How to scientifically formulate the specific implementation plan of practical teaching project, how to organize and implement scientifically, and strengthen the process management of practical teaching should be answered from the specific management and implementation process of practical teaching (Garvey, 2017; Guerrero and Roberts, 2017). 


\section{CONCLUSION}

This paper clarifies the status of practice teaching in the course of teaching reform, introduces the current situation of practice teaching in our country, analyzes the characteristics of the current teaching reform and the existing problems, and studies the design and principle of undergraduate practice teaching reform projects. The content system of practice teaching is proposed and the new practice teaching method is designed, and then the scheme security system is studied to promote innovation and development of university education teaching methods. The establishment concept, principle, implementation conditions and management of the protection system are brought up, and the evaluation index system of performance test of teaching practice scheme is studied, so as to put forward the evaluation method. This paper solves the key problems in the project design of the university practice teaching reform project, and establishes the implementation protection system of the practice teaching program, which is conducive to promoting the reform process of the university teaching mode.

\section{ACKNOWLEDGEMENT}

National Social Science Fund Project Youth Fund (No. 17CRK008); Shaanxi Provincial Education Department humanities and Social Sciences project (No. 17JK0173); Shaanxi higher education teaching reform project (No. 17BY107).

\section{REFERENCES}

Akre, C., \& Suris, J. C. (2017). Adolescents and young adults' perceptions of electronic cigarettes as a gateway to smoking: a qualitative study in Switzerland. Health Education Research, 32(5), 448-454.

Blonder, R., \& Sakhnini, S. (2017). Finding the connections between a high-school chemistry curriculum and nanoscale science and technology. Chemistry Education Research and Practice, 18(4), 903-922.

Collins, K., \& Staples, K. (2017). The role of physical activity in improving physical fitness in children with intellectual and developmental disabilities. Research in Developmental Disabilities, 69, 49-60.

Delman, J., Clark, J. A., Eisen, S. V., \& Parker, V. A. (2015). Facilitators and Barriers to the Active Participation of Clients with Serious Mental Illnesses in Medication Decision Making: the Perceptions of Young Adult Clients. Journal of Behavioral Health Services \& Research, 42(2), 1-16.

Deng, L., \& Zhang, X. (2017). Modeling and Simulation of teaching quality evaluation for promoting academic performance. Computer simulation, 34(07), 158-161.

Elmunzer, B. J., Singal, A. G., Sussman, J. B., Deshpande, A. R., Sussman, D. A., Conte, M. L., ..., Waljee, A. K. (2015). Comparing the effectiveness of competing tests for reducing colorectal cancer mortality: a network meta-analysis. Gastrointestinal Endoscopy, 81(3), 700-709.

Garvey, J. C. (2017). Considerations for Queer as a Sexual Identity Classification in Education Survey Research. Journal of College Student Development, 58(7), 1113-1118.

Goren, H., \& Yemini, M. (2017). The global citizenship education gap: Teacher perceptions of the relationship between global citizenship education and students' socio-economic status. Teaching and Teacher Education, $67,9-22$.

Gradl, G., Knobe, M., Pape, H. C., Neuhaus, P. V., Ring, D., \& Guitton, T. (2015). Decision making in displaced fractures of the proximal humerus: fracture or surgeon based? International Orthopaedics, 39(2), 29-34.

Guerrero, A. P., \& Roberts, L. W. (2017). Snapshots from the Cutting Edge: Innovations in Child and Adolescent Psychiatry Training to Address Workforce Shortages. Academic Psychiatry, 41(5), 571-573.

Han, S., \& Lee, S. (2017). College Student Binge Eating: Attachment, Psychological Needs Satisfaction, and Emotion Regulation. Journal of College Student Development, 58(7), 1074-1086.

Harris, J. C. (2017). Multiracial Campus Professionals' Experiences with Multiracial Microaggressions. Journal of College Student Development, 58(7), 1055-1073.

Hismanoglu, M. (2010). Language Learning Strategies in Foreign Language Learning and Teaching. Basic education foreign language teaching research, 12(6), 32-37.

$\mathrm{Hu}, \mathrm{X} . \mathrm{W}$. (2012). The vitality of the reform of university classroom teaching mode. The experience of learning and applying the "45341" University efficient classroom teaching mode. Heilongjiang Researches on Higher Education, 30(02), 18-19.

Instefjord, E. J., \& Munthe, E. (2017). Educating digitally competent teachers: A study of integration of professional digital competence in teacher education. Teaching and Teacher Education, 67, 37-45. 
John, A., \& Zapata Roblyer, M. (2017). Mothers Parenting a Child with Intellectual Disability in Urban India: An Application of the Stress and Resilience Framework. Intellectual and Developmental Disabilities, 55(5), 325-337.

Kwon, E. H., \& Block, M. E. (2017). Implementing the adapted physical education E-learning program into physical education teacher education program. Research in Developmental Disabilities, 69, 18-29.

LaChausse, R. G. (2017). A clustered randomized controlled trial to determine impacts of the Harvest of the Month program. Health Education Research, 32(5), 375-383.

Lawson, J. E., Cruz, R. A., \& Knollman, G. A. (2017). Increasing positive attitudes toward individuals with disabilities through community service learning. Research in Developmental Disabilities, 69, 1-7.

Liu, B. X. (2010). Factors affecting the action oriented teaching reform in vocational schools and Countermeasures -- Taking the teaching reform of Sino German Cooperative (Jiangxi) vocational education project school. China Vocational and technical education, 12(05), 24-28.

Manning, M., Lawrence, J., King, D. N., \& Chapman, R. (2015). Dealing with changing risks: a New Zealand perspective on climate change adaptation. Regional Environmental Change, 15(4), 581-594.

Mathews, H. M., Rodgers, W. J., \& Youngs, P. (2017). Sense-making for beginning special educators: A systematic mixed studies review. Teaching and Teacher Education, 67, 23-36.

Neto, F., \& Wilks, D. C. (2017). Predictors of Psychological Adaptation of Cape Verdean Students in Portugal. Journal of College Student Development, 58(7), 1087-1100.

Nwagu, E. N., Dibia, S. I. C., \& Odo, A. N. (2017). Socio-cultural norms and roles in the use and abuse of alcohol among members of a rural community in Southeast Nigeria. Health education research, 32(5), 423-436.

Odeh, B., Kayyali, R., Nabhani-Gebara, S., \& Philip, N. (2015). Optimizing cancer care through mobile health. Supportive Care in Cancer, 23(7), 2183-2188.

Or-Kan, S. (2017). Processing academic science reading texts through context effects: evidence from eye movements. EURASIA Journal of Mathematics, Science and Technology Education, 13(3), 771-790. doi:10.12973/eurasia.2017.00642a

Saunders, W., Grace, E., Beban, J., \& Johnston, D. (2015). Evaluating Land Use and Emergency Management Plans for Natural Hazards as a Function of Good Governance: A Case Study from New Zealand. International Journal of Disaster Risk Science, 6(1), 62-74.

Shilova, Z. V., \& Sibgatullina, T. V. (2017). Methodology features of teaching stochastics to university students of the biology specialization. EURASIA Journal of Mathematics, Science and Technology Education, 13(8), 47254738. doi:10.12973/eurasia.2017.00960a

Singh-Pillay, A., \& Sotsaka, D. S. (2017). Engineering graphics and design teachers' understanding and teaching of assembly drawing. EURASIA Journal of Mathematics, Science and Technology Education, 13(5), 1213-1228. doi:10.12973/eurasia.2017.00668a

Starks, H., Shaw, J. L., Hiratsuka, V., Dillard, D. A., \& Robinson, R. (2015). Engaging stakeholders to develop a depression management decision support tool in a tribal health system. Quality of Life Research, 24(5), 10971105.

Stoehr, A., Benders, T., van Hell, J. G., \& Fikkert, P. (2017). Second language attainment and first language attrition: The case of VOT in immersed Dutch-German late bilinguals. Second Language Research, 33(4), 483-518.

Tala, S., \& Vesterinen, V. M. (2015). Nature of Science Contextualized: Studying Nature of Science with Scientists. Science \& Education, 24(4), 435-457.

Wang, L., Feng, Z., \& Yang, Y. (2015). The change in population density from 2000 to 2010 and its influencing factors in China at the county scale. Journal of Geographical Sciences, 25(4), 485-496.

Yi, W., Lu, S., \& Ma, G. (2017). Frequency, contingency and online processing of multiword sequences: An eyetracking study. Second Language Research, 33(4), 519-549.

Zhao, C. L., Wang, W., \& Chang, L. (2013). Teaching mode reform and practice of University Students' health education. Chinese Journal of School Health, 34(09), 1034-1035.

Zhong, Z., Huang, R., Tang, Q., Cong, X., \& Wang, Z. (2015). China's provincial CO2, emissions embodied in trade with implications for regional climate policy. Frontiers of Earth Science, 9(1), 77-90.

\section{http://www.ejmste.com}

